\title{
THE EFFECT OF CAFFEINE SUPPLEMENTATION ON EXERCISE PERFORMANCE EVALUATED BY A NOVEL ANIMAL MODEL
}

Clin Biomed Res. 2017;37(4):316-322

1 Graduate Program in Cardiology and Cardiovascular Sciences, Universidade Federal do Rio Grande do Sul (UFRGS) Porto Alegre, RS, Brazil.

2 Interdisciplinary Sleep Research Laboratory, Hospital de Clínicas de Porto Alegre (HCPA). Porto Alegre, RS, Brazil.

3 Graduate Program in Medical Sciences, Universidade Federal do Rio Grande do Sul (UFRGS). Porto Alegre, RS, Brazil.

4 Cardiology Unit, Hospital de Clínicas de Porto Alegre (HCPA). Porto Alegre, RS, Brazil.

Corresponding author: Roberto Pacheco da Silva roberto.pacheco01@gmail.com Cardiology Unit, Hospital de Clínicas Porto Alegre (HCPA)

Rua Ramiro Barcelos, 2350

90035-903, Porto Alegre, RS, Brazil.

\section{Roberto Pacheco da Silva ${ }^{1,2}$, Denis Martinez ${ }^{1,2,3,4}$, Cintia Zappe Fiori ${ }^{1,2}$, Kelly Silveira da Silva Bueno ${ }^{1,2}$, Jhoana Mercedes Uribe Ramos ${ }^{2,3}$, Renata Schenkel Kaminski ${ }^{2,3}$, Marcia Kraide Fischer ${ }^{2,3}$, Leticia Maria Tedesco Silva ${ }^{1,2}$, Juliana Neves Giordani ${ }^{2,3}$, Juliana Heitich Brendler ${ }^{2}$, Juliana Langendorf da Costa Vieira², Yasmin de Freitas Dias ${ }^{2}$, Laura Martinewski de Oliveira², Chaiane Facco Piccin ${ }^{1,2}$, Emerson Ferreira Martins ${ }^{1,2}$}

\begin{abstract}
Introduction: Caffeinated drinks are used for improve performance. Animal models represent investigational strategy that circumvents most of the drawbacks of research in humans, including motivational factors and the placebo effect. No animal model that could test whether different forms of administering caffeine affect exercise propensity was found in the literature.
\end{abstract}

Methods: An animal model of grouped voluntary exercise was tested. Two-month-old male C57/bl mice were housed in a cage fitted with one running wheel and a monitoring system. Six animals per cage were introduced individually. To assess the sensitivity of the model, the effect of different caffeinated drinks was observed in mice exercising ad libitum. During 2 days, the mice received: 1) pure anhydrous caffeine $0.125 \mathrm{mg} / \mathrm{mL}$ (PC), 2) cola drink (CC), and 3) caffeine-taurine-glucuronolactone drink (CTG), intercalating wash-out periods of 2 days, receiving pure water.

Results: The distance run during the periods of water ingestion was significantly lower than during the periods of stimulant drinks ingestion: $P C(5.6 \pm 1.3 \mathrm{~km} ; p=0.02)$, of CC ingestion (7.6 $\pm 0.6 \mathrm{~km} ; p=0.001)$, and of CTG ingestion $(8.3 \pm 1.6 \mathrm{~km} ; p=0.009)$. The performances when ingesting the three caffeinated drinks do not follow a dose-response curve.

Conclusions: The model described here was able to measure the effect of caffeine intake on voluntary exercise of mice. The sensitivity of the model to the effect of caffeine needs to be further validated. The action of each component of the drinks on exercise performance needs to be clarified in future research. The present model is adequate for such investigation.

Keywords: Exercise; caffeine; energy drinks; running

Athletic performance depends both on the athlete's motivation on a set of complex physiological and psychological phenomena, including placebo effect, with different degrees of influence ${ }^{1-6}$.

Evaluation of changes in performance in humans is further encumbered owing to genetic and cultural variability. To minimize these and other issues of human trials, experimentation with laboratory animals is desirable as first step before results are translated to human settings.

Most exercise models keep the animals isolated in a cage containing an exercise wheel ${ }^{7-9}$. For rodents, this is a potent stressor ${ }^{10,11}$. Other types of models force the animals to run in treadmills ${ }^{12-14}$, using electric shocks ${ }^{15,16}$ or brushes ${ }^{17}$ to motivate them. An extensive literature search did not find experiments utilizing grouped animals and adding their combined activity 
to assess exercise performance or propensity that could be used to compare in animals, point by point, the seven conclusions derived by the International Society of Sports Nutrition from humans ${ }^{18}$.

Running wheels are employed for enrichment of cages. Rodents are naturally affectionate of running wheels. When observing pets, one can identify the sharing of running wheels. We hypothesized that grouping mice in a cage with access to an exercise wheel is a viable model to test exercise performance. The model was imagined as a "black box" in which an input - caffeine - is introduced and the number of kilometers run emerges as an output.

This study aimed to investigate the ability of a hypothesized animal model to assess running propensity in mice. The effect of different caffeine preparations on the amount of exercise performed was used as an indicator of the sensitivity of the model to interventions that may increase or decrease predisposition to exercise.

\section{METHODS}

\section{Animals}

Two-month-old male C57/bl mice (FEPPS, Porto Alegre, Brazil) were housed under temperatures ranging between 22.5 and $24.5^{\circ} \mathrm{C}$ and received $a d$ libitum standard mice chow (Purina-Nutripal, Porto Alegre, RS, Brazil). The protocol was approved by the institutional Ethics Committee and followed the Guide for the Care and Use of Laboratory Animals ${ }^{19}$.

\section{Microprocessor System for Monitoring Exercise}

The activity of the animals on the exercise wheel was measured by a lap counter developed in our institution. The monitoring equipment was operated by a Hall-effect non-contact bipolar digital switch, a standalone microcontroller with LCD display, and a serial interface. The date, time, total number of turns, and turns per minute were stored for downloading to a computer. Software was developed to transfer and graphically represent the data on a display. The number of turns run by the mice was converted to kilometers, based on the wheel circumference of $31.4 \mathrm{~cm}$.

\section{Exercise System}

The cage had two compartments isolated by a door that was open or closed to control access to the compartment enclosing the running wheel (Figure 1). The other compartment was a regular cage with access to food and to a gravity-fed water bottle. From 9 a.m. to 5 p.m., in the light period, the animals were isolated from the exercise wheel to prevent activity during the sleep time, ensuring at least 8 hours of rest.

Protocol Phase 1-Developing an exercise group protocol: In the first phase of the experiment, the operational viability of the exercise model was established. In this phase, each animal was placed alone in a cage with access to the exercise wheel from 5 p.m. to 9 a.m. After two or three nights, depending on the variability from night to night, individual interest by the wheel was confirmed by a distance run of at least $0.1 \mathrm{~km}$. Afterwards, one animal by night was added to the group in the cage to verify whether the distance would increase. The optimal number of animals per cage would be determined when "saturation" of exercise wheel occurred, i.e., when the sum of the distance run on the wheel would not increase as more animals were introduced in the cage. Six animals were placed on each cage without saturation. This number was maintained because the area of the cage did not allow more animals, within the standards of animal care. Each day, each cage produced one summed number

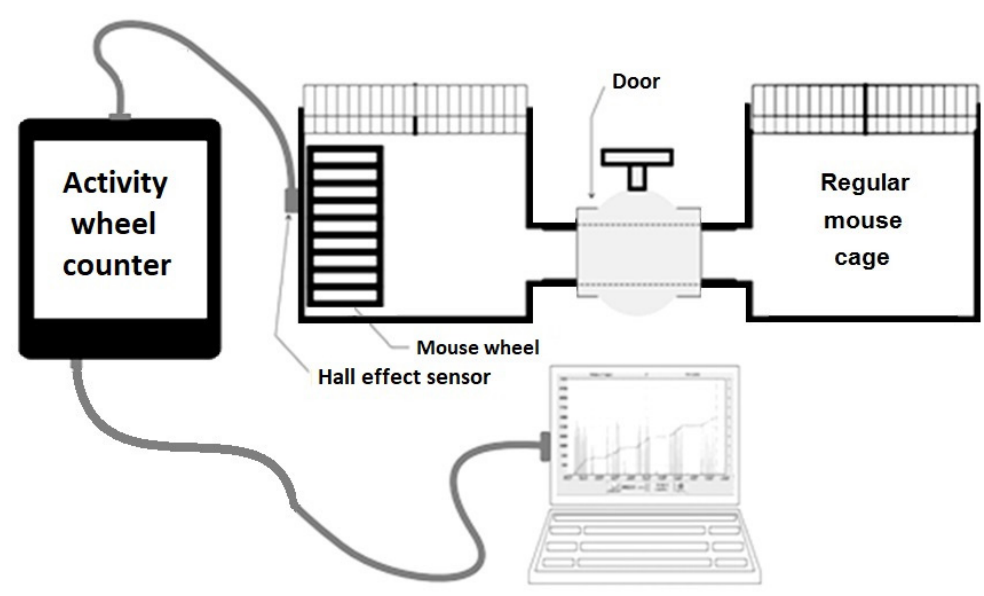

Figure 1: Exercise system. 
of turns. The results of the two cages were averaged daily. During 1 week, until the beginning of phase 2, mice had free access to the exercise wheel 16 hours per day, from 5 p.m. to 9 a.m. In this period, the number of turns increased and eventually stabilized.

Protocol Phase 2 - Stimulant interventions: The interventions were applied after the number of six mice per cage was established and the daily number of turns was stable. A total of 12 mice were tested in two separate cages. Each group with six mice exercised 2 days receiving pure water to establish the baseline distance run. After

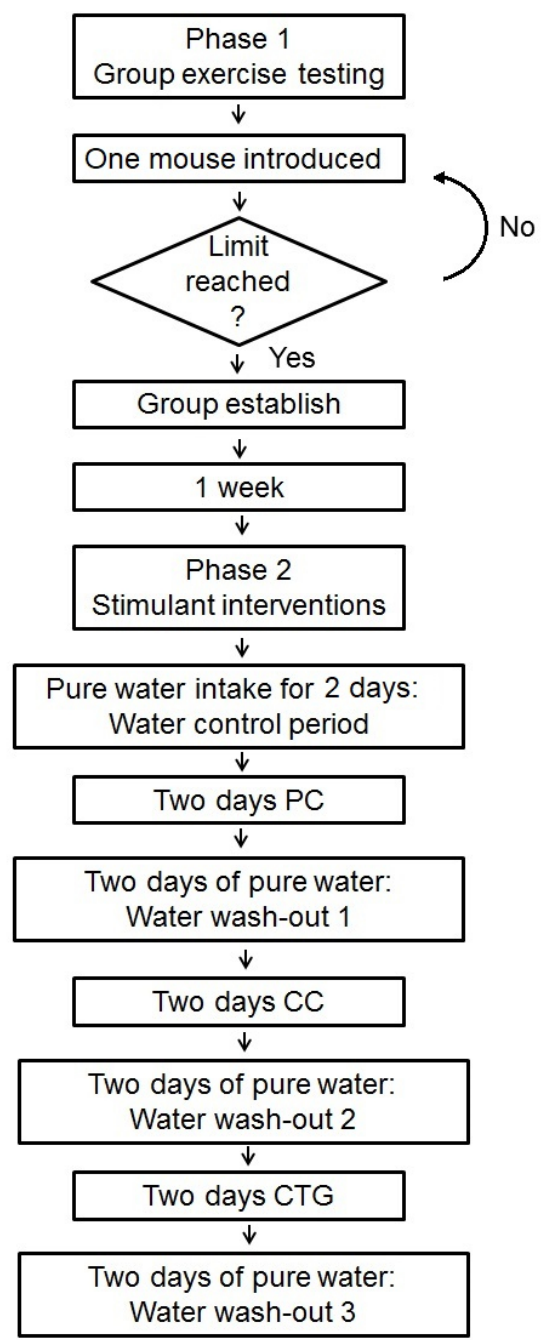

Figure 2: Flow diagram of the experiment. that, they alternated 2 days drinking stimulant with 2 days of wash-out drinking pure water for the three stimulants (pure caffeine [PC], cola + caffeine [CC], caffeine + taurine + glucuronolactone [CTG]) (Figure 2). The stimulants received are described in Table 1. The gas in the drinks was removed by shaking. The whole experiment lasted 14 days.

\section{Statistical Analysis}

Each data point represents the average of four distances measured in two cages during 2 days. The results were presented as mean \pm standard deviation in tables and as mean \pm one standard error in graphical form. The data were compared using paired-samples t-test or, when appropriate, one-way ANOVA, followed by Tukey's b post-hoc test. Data were analyzed using SPSS for Windows v.16 (SPSS Chicago, IL). Significance level for alpha error was set at 0.05 .

\section{RESULTS}

The accumulated distance run by day in each cage with six mice is shown in Table 2. At the beginning of the experiment, mechanical problems with the wheel led to data loss in each one of the two cages. Therefore, the result for Water 1 is for only one cage in day 2 and the result for PC is for only one cage in day 1.

Figure 3 shows four panels reproducing the display of the monitoring software. Each panel represents one test period lasting 16 hours. A clear increase in speed and duration of activity is seen in panels b, c, and $d$, recorded when animals were under stimulant effect, as compared with panel a, recorded when the mice received water to drink. Activity in the light-on period was minimal.

All periods receiving stimulant were different from the previous water period. In the period receiving PC, the mean distance run increased $3 \mathrm{~km}$ when compared with the control period. In the period receiving the CTG drink, the mean distance run was the largest but not statistically different from the other stimulants. All wash-out periods presented significant reduction in running activity from stimulant period except for wash-out 1 (Figure 4).

Table 1: Composition of caffeinated drinks.

\begin{tabular}{cccl}
\hline Caffeinated drinks & Caffeine dose & Carbohydrates & \multicolumn{1}{c}{ Calories } \\
\hline Pure caffeine & $0.125 \mathrm{mg} / \mathrm{mL}$ & $0.015 \mathrm{~g} / \mathrm{mL}$ & $0.06 \mathrm{Kcal} / \mathrm{mL}$ \\
Cola drink & $0.095 \mathrm{mg} / \mathrm{mL}$ & $0.105 \mathrm{~g} / \mathrm{mL}$ & $0.425 \mathrm{Kcal} / \mathrm{mL}$ \\
CTG & $0.32 \mathrm{mg} / \mathrm{mL}$ & $0.112 \mathrm{~g} / \mathrm{mL}$ & $0.44 \mathrm{Kcal} / \mathrm{mL}$ \\
\hline
\end{tabular}

$\mathrm{CTG}=$ caffeine + taurine + glucuronolactone . 
Table 2: Distance run $(\mathrm{km})$ by cage on the first and second day of interventions.

\begin{tabular}{ccccccccc}
\hline Day & Cage & Water 1 & PC & Water 2 & CC & Water 3 & CTG & Water 4 \\
\hline 1 & 1 & 2.9 & - & 4.5 & 8.4 & 5.1 & 9.6 & 5.6 \\
1 & 2 & 2.9 & 7.1 & 4.9 & 7.6 & 5.9 & 6.8 & 6.8 \\
2 & 1 & 2.0 & 4.9 & 3.0 & 7.1 & 4.3 & 9.8 & 2.1 \\
2 & 2 & - & 4.9 & 3.8 & 7.1 & 4.3 & 7.0 & 3.8 \\
Mean & & 2.6 & 5.6 & $4.1^{*}$ & $7.6^{\#}$ & 4.6 & 8.3 & 4.6 \\
SD & & 0.5 & 1.3 & 0.8 & 0.6 & 2.0 & 1.6 & 1.8 \\
\hline
\end{tabular}

*Significantly different from control period. "Significantly different from PC.

$\mathrm{SD}=$ standard deviation; $\mathrm{PC}=$ pure caffeine; $\mathrm{CC}=$ cola + caffeine; $\mathrm{CTG}=$ caffeine + taurine + glucuronolactone .

a

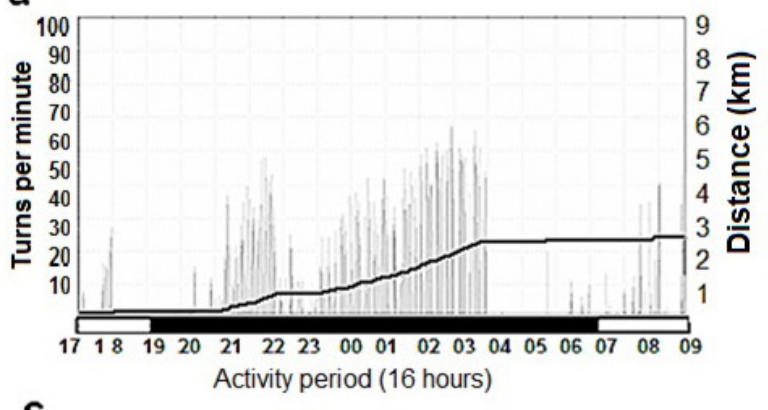

C

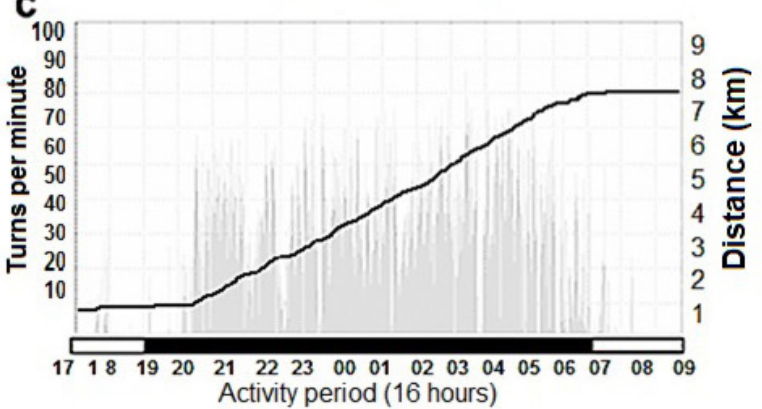

b

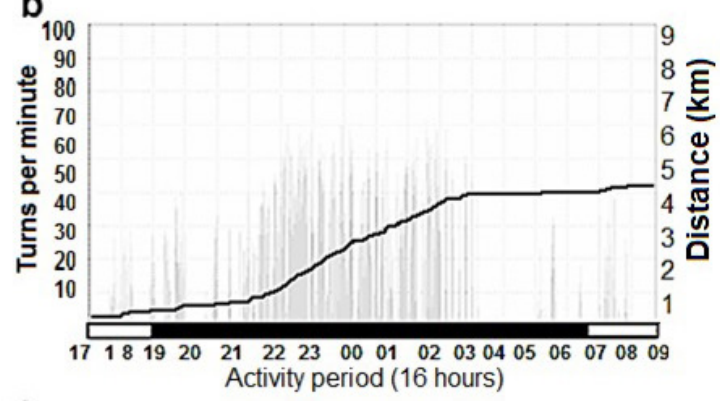

d

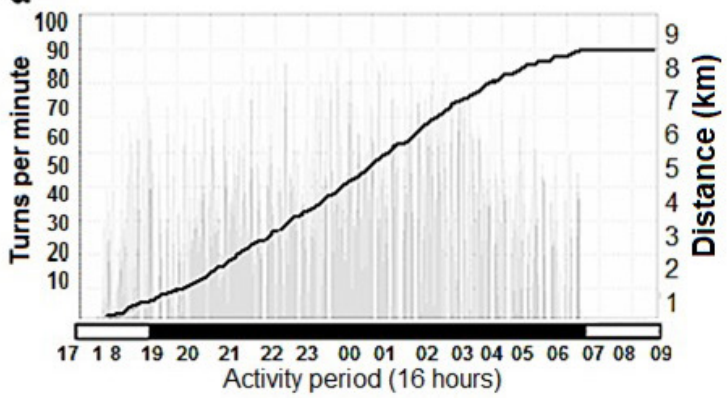

Figure 3: Display of the monitoring software with 16-hour record of exercise wheel activity. The height of each vertical grey line represents the number of turns in exercise wheel in one-minute epochs as seen at the left axis. The black line represents the sum of turns over time and the total of kilometers run is seen at the right axis. Panel a, animals receiving water; Panel b, animals receiving pure caffeine; Panel c, animals receiving cola drink; Panel d, animals receiving caffeine + taurine + glucuronolactone.

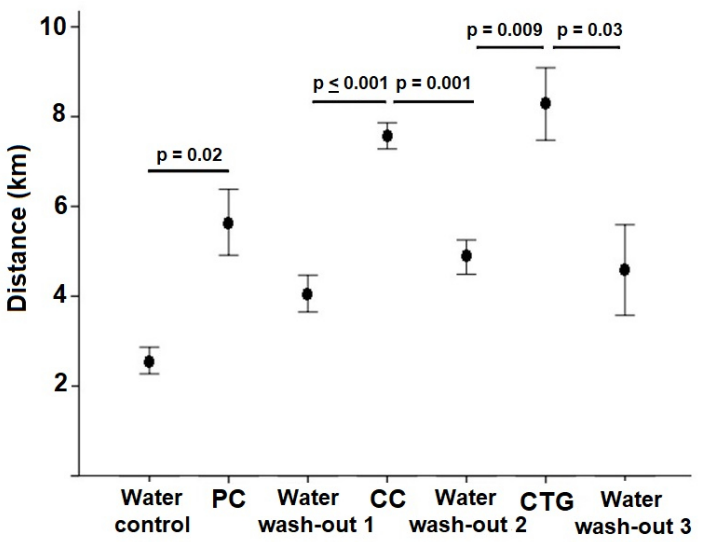

Figure 4: Means of distance run, standard errors of the means, and significance of the differences in distance run between periods receiving water and stimulants. $P C=$ pure caffeine; $\mathrm{CC}=$ cola drink $; \mathrm{CTG}=$ caffeine + taurine + glucuronolactone .

\section{DISCUSSION}

To the best of our knowledge, this is the first report of a voluntary exercise model for rodents using the distance run by a group as outcome. The distance run in one wheel increased as more mice were introduced in the group, up to a number of six mice per cage, and when caffeine were provided. With the mice running ad libitum, the model detected increase in exercise during periods under influence of caffeine and, as expected, decrease of distance in periods receiving water.

To collect exercise data from the distance run voluntarily by groups of six mice provides results in a fast, animal-friendly, and low-cost way. Exercise models that keep the animals isolated may induce stress ${ }^{9,10}$. Likewise, the use of treadmills and electrical shock 
to force exercise ${ }^{14,15}$ may introduce difficulties in the assessment of the propensity to exercise. In the present model, besides the natural colony environment being maintained, one mouse running in front of the group may entice the overall activity, creating an "exercise culture". In such a social setting, activity may reflect more closely what happens with exercising humans.

Since this report is preliminary, several limitations can be encountered. Among the limitations, the lack of a control group for comparison, exposed to another performance recording method, is an issue. Future research using a proper controlled design to compare the present model with alternative models is necessary. Also, by summing up the performance of all animals in the cage, the model limits the number of data points to one per cage per day. Instead of detecting inter-individual differences, the standard deviation in Table 2 and standard error in Figure 4 represent the dispersion of the four data points of two cages in 2 days. To increase the number of data points, distances could be computed and analyzed at certain time intervals or even hourly. This can be useful for research of chronobiological aspects of exercise. All these possibilities are beyond the scope of the present study.

Complete validation of the model as for quantitative dose-response measurements was not achieved by the present study. It was not assumed that each one of the animals in the cage consumed similar amounts of each one of the drinks offered. The model is to be seen as a "black box". The participation of each animal is not measured but assumed. In this respect, the use of isogenic animals seemed more reasonable. It is, however, necessary to test this model using different lineages of wild and isogenic rodents before a conclusion is reached on the best configuration of the box.

In Phase I, it was anticipated that when more mice were introduced in the exercise cage, the reduction of space per animal would create a stressful environment and reduce the activity. The distance, however, increased consistently when more animals were introduced in the cage. This is probably due to the fact that the animals in each cage were from the same litter and were lodged together since birth.

Understandably, the present model, due to its simplicity, has its utility circumscribed to experiments in which individual performance is not being evaluated. Experiments for assessment of each single animal performance are more complex, demanding equipment for swimming, treadmills, and other devices ${ }^{11-16}$. The utility of grouped voluntary exercise is more evident in the evaluation of interventions that increase or decrease the propensity to exercise. The input to be tested could be, for instance, hypoxia, sleep deprivation, obesity, and nutritional changes.

The appropriate choice of the experiment in which the model will be used is essential. The issue of the participation of each animal in grouped exercise not being actually recorded but rather assumed based on the overall increase in distance run cannot be circumvented in this model. The experiment, therefore, should cause a group effect. The whole cage being exposed in a reasonably uniform fashion to the intervention would obviate the need to record individual exercise.

Dose-response measurements were not performed in the present study. The plasma levels of caffeine are dubious, since it cannot be assumed that each one of the animals in the cage consumed similar amounts of each one of the drinks offered. Caffeine given by gavage or injection in progressive dosages would answer this doubt. The model, however, is adequate for this experiment.

Caffeine concentration in a drink does not predict the dose ingested. This was the case with CC drink that caused significantly greater running than PC with lower caffeine concentration. The smaller effect of $\mathrm{PC}$, compared to that of carbohydrate-containing $\mathrm{CC}$, can be due to: 1) inability of the model to detect a precise dose-response curve, 2) the calories provided by sugar increased exercise ability under $\mathrm{CC}$, and 3 ) the sweet taste prompted liquid ingestion beyond the necessary for thirst satiation, increasing plasmatic caffeine levels.

Effects of stimulant drinks ${ }^{20-22}$ are related primarily to the presence of caffeine in the composition. In the literature, the effect of drinks composed by CTG on exercise performance has been compared against placebo ${ }^{23-28}$. In humans, improved athletic performance after taking 3-6 mg of caffeine per kg of body weight, has been described in different types of exercise, especially in endurance activities ${ }^{29-31}$. A significant increase in resistance to exhaustion was seen with caffeine compared to placebo ${ }^{32,33}$. The performance of athletes after consuming drinks containing caffeine and taurine is increased ${ }^{34,35}$. Neither comparison of CTG against other caffeinated drinks nor successful establishment of a dose-response curve for caffeine ${ }^{36}$ in humans were found in the literature.

Even after 1 week of the first phase, in which animals stabilized the distance run, an increase in performance between the periods 1 and 2 receiving water was observed (Figure 4). The wash-out water period after PC shows a non-significant reduction from the PC period. This may reflect, at least in part, the effect of training. It is less likely that the wash-out period is insufficient since, under CC and CTG, the distance reverted to baseline. In future studies, the 
phase- 1 training in the wheel may be longer than 1 week to avoid this potential issue.

In conclusion, the efficacy of caffeine as a performance-enhancer was confirmed in a novel model of grouped exercise. The model described here was able to measure the effect of caffeine intake on voluntary exercise of mice, consonant with results in humans. The sensitivity of the model to the effect of caffeine needs to be further validated. The action of each component of the drinks on exercise performance needs to be clarified in future research. The present model is adequate for such investigation.

\section{Acknowledgements}

We thank the staffs from the Animal Experimentation Unit and Biomedical Engineering Unit of the HCPA for their support during the study.

\section{Conflicts of interest}

The authors declare no conflicts of interest.

\section{REFERENCES}

1. Davis JM, Bailey SP. Possible mechanisms of central nervous system fatigue during exercise. Med Sci Sports Exerc. 1997;29(1):4557. PMid:9000155. http://dx.doi. org/10.1097/00005768-19970100000008.

2. Beedie CJ, Foad AJ. The placebo effect in sports performance: a brief review. Sports Med. 2009;39(4):31329. PMid:19317519. http://dx.doi. org/10.2165/00007256-20093904000004.

3. Juhn M. Popular sports supplements and ergogenic aids. Sports Med. 2003;33(12):921-39. PMid:12974658. http://dx.doi.org/10.2165/00007256200333120-00004.

4. Maughan RJ, King DS, Lea T. Dietary supplements. J Sports Sci. 2004;22(1):95-113. PMid:14971436. http://dx.doi.org/10.1080/0264041031 000140581

5. Maughan R. The athlete's diet: nutritional goals and dietary strategies. Proc Nutr Soc. 2002;61(1):8796. PMid:12002799. http://dx.doi. org/10.1079/PNS2001132.

6. Coyle EF. Fluid and fuel intake during exercise. J Sports Sci. 2004;22(1):3955. PMid:14971432. http://dx.doi.org/1 0.1080/0264041031000140545.

7. Fredriksson A, Stigsdotter IM, Hurtig A, Ewalds-Kvist B, Archer T. Running wheel activity restores MPTP-induced functional deficits. $J$ Neural Transm. 2011;118(3):407-20. PMid:20852902. http://dx.doi.org/10.1007/s00702-0100474-8.

8. Meissner M, Nijstad N, Kuipers F, Tietge UJ. Voluntary exercise increases cholesterol efflux but not macrophage reverse cholesterol transport in vivo in mice. Nutr Metab (Lond). 2010;7(1):54. PMid:20594315. http://dx.doi.org/10.1186/1743-7075-754.

9. Kariya F, Yamauchi H, Kobayashi K, Narusawa M, Nakahara Y. Effects of prolonged voluntary wheel-running on muscle structure and function in rat skeletal muscle. Eur J Appl Physiol. 2004;92(1-2):90-7. PMid:15014999. http://dx.doi.org/10.1007/s00421-0041061-1.

10. Brain P. What does individual housing mean to a mouse? Life Sci. 1975;16(2):187-200. PMid:1089186. http://dx.doi.org/10.1016/00243205(75)90017-X.

11. Martin AL, Brown RE. The lonely mouse: Verification of a separationinduced model of depression in female mice. Behav Brain Res. 2010;207(1):196-207. PMid:19819265. http://dx.doi.org/10.1016/j. bbr.2009.10.006.

12. Baker EJ, Gleeson TT. The effects of intensity on the energetics of brief locomotor activity. J Exp Biol. 1999;202(Pt 22):3081-7. PMid:10539956.

13. Waters RE, Rotevatn S, Li P, Annex $\mathrm{BH}$, Yan Z. Voluntary running induces fiber type-specific angiogenesis in mouse skeletal muscle. Am J Physiol Cell Physiol. 2004;287(5):C13428. PMid:15253894. http://dx.doi. org/10.1152/ajpcell.00247.2004.

14. Lajoie C, Calderone A, Béliveau L. Exercise training enhanced the expression of myocardial proteins related to cell protection in spontaneously hypertensive rats. Pflugers Arch. 2004;449(1):2632. PMid:15290300. http://dx.doi. org/10.1007/s00424-004-1307-0.
15. Powers SK, Demirel HA, Vincent HK, Coombes JS, Naito H, Hamilton $\mathrm{KL}$, et al. Exercise training improves myocardial tolerance to in vivo ischemia-reperfusion in the rat. $A m \mathrm{~J}$ Physiol. 1998;275(5 Pt 2):R1468-77. PMid:9791063.

16. Huang CC, Lin WT, Hsu FL, Tsai PW, Hou CC. Metabolomics investigation of exercise-modulated changes in metabolism in rat liver after exhaustive and endurance exercises. Eur $J$ Appl Physiol. 2010;108(3):55766. PMid:19865828. http://dx.doi. org/10.1007/s00421-009-1247-7.

17. Kyparos A, Sotiriadou S, Mougios V, Cheva A, Barbanis S, Karkavelas $G$, et al. Effect of 5-day vitamin E supplementation on muscle injury after downhill running in rats. Eur $\mathrm{J}$ Appl Physiol. 2011;111(10):255769. PMid:21369732. http://dx.doi. org/10.1007/s00421-011-1888-1.

18. Campbell B, Wilborn C, La Bounty P, Taylor L, Nelson MT, Greenwood $M$, et al. International Society of Sports Nutrition position stand: energy drinks. J Int Soc Sports Nutr. 2013;10(1):1. PMid:23281794. http:// dx.doi.org/10.1186/1550-2783-10-1 .

19. Committee for the Update of the Guide for the Care and Use of Laboratory Animals. The Guide for the Care and Use of Laboratory Animals. Washington: The National Academies Press; 2016.

20. Bucci LR. Selected herbals and human exercise performance. Am J Clin Nutr. 2000;72(2 Suppl):624S-36S. PMid:10919969.

21. Graham TE. Caffeine and exercise: metabolism, endurance and performance. Sports Med. 
2001;31(11):785-807. PMid:11583104. http://dx.doi.org/10.2165/00007256200131110-00002.

22. Paluska SA. Caffeine and exercise. Curr Sports Med Rep. 2003;2(4):2139. PMid:12834577. http://dx.doi. org/10.1249/00149619-20030800000008.

23. Del Coso J, Estevez E, MoraRodriguez R. Caffeine during exercise in the heat: thermoregulation and fluid-electrolyte balance. Med Sci Sports Exerc. 2009;41(1):16473. PMid:19092693. http://dx.doi. org/10.1249/MSS.0b013e318184f45e.

24. Cox GR, Desbrow B, Montgomery PG, Anderson ME, Bruce CR, Macrides $\mathrm{TA}$, et al. Effect of different protocols of caffeine intake on metabolism and endurance performance. $J$ Appl Physiol. 2002;93(3):9909. PMid:12183495. http://dx.doi. org/10.1152/japplphysiol.00249.2002.

25. Lin FJ, Pierce MM, Sehgal A, Wu T, Skipper DC, Chabba R. Effect of taurine and caffeine on sleep-wake activity in Drosophila melanogaster. Nat Sci Sleep. 2010;2:221-31. PMid:23616711. http://dx.doi. org/10.2147/NSS.S13034.

26. Ganio MS, Klau JF, Casa DJ, Armstrong LE, Maresh CM. Effect of caffeine on sport-specific endurance performance: a systematic review. $J$
Strength Cond Res. 2009;23(1):31524. PMid:19077738. http://dx.doi. org/10.1519/JSC.0b013e31818b979a.

27. Ivy JL, Kammer L, Ding Z, Wang B, Bernard JR, Liao Y-H, et al. Improved cycling time-trial performance after ingestion of a caffeine energy drink. Int J Sport Nutr Exerc Metab. 2009;19(1):61-78. PMid:19403954. http://dx.doi.org/10.1123/ ijsnem.19.1.61.

28. Claghorn GC, Thompson Z, Wi K, Van L, Garland T JR. Caffeine stimulates voluntary wheel running in mice without increasing aerobic capacity. Physiol Behav. 2017;170:13340. PMid:28039074. http://dx.doi. org/10.1016/j.physbeh.2016.12.031.

29. Sinclair CJ, Geiger JD. Caffeine use in sports. A pharmacological review. J Sports Med Phys Fitness. 2000;40(1):71-9. PMid:10822912.

30. Graham TE, Rush JWE, Soeren MH VAN. Caffeine and exercise: metabolism and performance. Can J Appl Physiol. 1994;19(2):11138. PMid:8081318. http://dx.doi. org/10.1139/h94-010.

31. Jackman $M$, Wendling $P$, Friars $D$, Graham TE. Metabolic catecholamine, and endurance responses to caffeine during intense exercise. $J$ Appl Physiol. 1996;81(4):1658-63. PMid:8904583.
32. Burke LM. Caffeine and sports performance. Appl Physiol Nutr Metab. 2008;33(6):1319-34. PMid:19088794. http://dx.doi. org/10.1139/H08-130.

33. Sökmen B, Armstrong LE, Kraemer WJ, Casa DJ, Dias JC, Judelson DA, et al. Caffeine use in sports: considerations for the athlete. $J$ Strength Cond Res. 2008;22(3):97886. PMid:18438212. http://dx.doi. org/10.1519/JSC.0b013e3181660cec.

34. Geiß KR, Jester I, Falke W, Hamm $M$, Waag KL. The effect of a taurinecontaining drink on performance in 10 endurance-athletes. Amino Acids. 1994;7(1):45-56. PMid:24185972. http://dx.doi.org/10.1007/BF00808445.

35. Baum M, Weiss $M$. The influence of a taurine containing drink on cardiac parameters before and after exercise measured by echocardiography. Amino Acids. 2001;20(1):75-82. PMid:11310932. http://dx.doi. org/10.1007/s007260170067.

36. Desbrow B, Barrett CM, Minahan CL, Grant GD, Leveritt MD. Caffeine, cycling performance, and exogenous $\mathrm{CHO}$ oxidation: a dose-response study. Med Sci Sports Exerc. 2009;41(9):1744-51. PMid:19657295. http://dx.doi.org/10.1249/ MSS.0b013e3181a16cf7. 